\title{
Perceived Factors Affecting Students' Academic Achievement in Secondary Schools in Bongao District
}

\author{
Rubia A. Abdulwahab ${ }^{1}$ \\ ${ }^{1}$ Mindanao State University-Tawi-Tawi, Bongao, Tawi-Tawi, Philippines
}

\begin{abstract}
Achievement in Education is the best legacy that a nation can give to her citizens especially the youth. This is because the development of any nation or community depends largely on the quality of education of such nation. It is also agreed that formal education remains the vehicle for socio-economic, psychological and environmental development of any society of which the students are the hope of the progress. However, a student's achievement is dependent on a combination of many factors. There is no "one-size-fits-all" rule to academic achievement, but there does seem to be a pattern among youth who do particularly well in school.
\end{abstract}

Keywords: Perceived Factors, Academic Achievement, Secondary Schools

\section{Introduction}

Achievement in Education is the best legacy that a nation can give to her citizens especially the youth. This is because the development of any nation or community depends largely on the quality of education of such nation. It is also agreed that formal education remains the vehicle for socio-economic, psychological and environmental development of any society of which the students are the hope of the progress. However, a student's achievement is dependent on a combination of many factors. There is no "one-size-fits-all" rule to academic achievement, but there does seem to be a pattern among youth who do particularly well in school.

Measuring of students' academic achievement is challenging since students' academic achievement is product of numerous factors. These variables are inside and outside school that affect students' quality of academic achievement.

Students with different perspective in life, especially those in Bongao Municipality are affected by myriad of factors. The researcher chooses the locale of the study because students' respondents in the said area have different perspectives, motivations, experiences, and achievement level which may be traced from their Family life, Socio-economic status, Physical factors, Environmental factors, and the School factors.

\section{Problem Statements}

1. What is the profile of the students' respondents in terms of:
a. School Attended
b. Gender
c. Educational Attainment of Parents
d. Monthly Income of Parents

2. What are the determinants/indicators that affect the students' academic achievements along the following variables:

*Internal factors * External factors

3. Is there a significant influence of internal factors and external factors to the Academic Achievements of the students in terms of: 


\section{Methods}

This research utilizes the survey approach of research using descriptive correlational method. The research sample was constituted of Third year High School or Grade Nine (9) students of Bongao District. It comprises of eleven (11) schools with three distinct institutes; Public High Schools, Private High Schools, Laboratory High Schools and Vocational High Schools. The main used to gather and collect data was a non-standardized survey questionnaire checklist form that contain all necessary conditions, situations, and problems developed based on the review of related literature, related studies, ideas, and observations of the researcher about the topic of the study.

Results

1. What is the profile of the students' respondents in terms of:
a. School Attended
c. Monthly Income of Parents
b. Gender
d. Educational Attainment of Parents

Distribution of Student-Respondents By School

\begin{tabular}{|c|l|c|c|c|}
\hline School Code & School_name & Frequency & Percent & Cumulative Percent \\
\hline 1 & ACLCFI & 10.00 & 1.95 & 1.95 \\
\hline 2 & BSTHS & 27.00 & 5.26 & 7.21 \\
\hline 3 & BAA & 26.00 & 5.07 & 12.28 \\
\hline 4 & MITHS & 34.00 & 6.63 & 18.91 \\
\hline 5 & PNHS & 48.00 & 9.36 & 28.27 \\
\hline 6 & PHS & 77.00 & 15.01 & 43.27 \\
\hline 7 & SSNHS & 17.00 & 3.31 & 46.59 \\
\hline 8 & SHS & 28.00 & 5.46 & 52.05 \\
\hline 9 & TRACHS & 47.00 & 9.16 & 61.21 \\
\hline 10 & TTSAT & 103.00 & 20.08 & 81.29 \\
\hline 11 & TTSF & 96.00 & 18.71 & 100.00 \\
\hline & Total & $\mathbf{5 1 3 . 0 0}$ & $\mathbf{1 0 0 . 0 0}$ & \\
\hline
\end{tabular}

Distribution of Student-Respondents By Gender

\begin{tabular}{|l|r|r|r|}
\hline \multicolumn{1}{|c|}{ Gender_id } & Frequency & Percent & $\begin{array}{c}\text { Cumulative } \\
\text { Percent }\end{array}$ \\
\hline Male & 190.00 & 37.04 & 37.04 \\
\hline Female & 323.00 & 62.96 & 100.00 \\
\hline Total & 513.00 & 100.00 & \\
\hline
\end{tabular}

Distribution of Student-Respondents' Parents Monthly Income

\begin{tabular}{|l|r|r|r|}
\hline \multicolumn{1}{|c|}{ Income_id } & Frequency & Percent & $\begin{array}{c}\text { Cumulative } \\
\text { Percent }\end{array}$ \\
\hline Less than 3,000 Pesos & 215.00 & 41.91 & 41.91 \\
\hline 3,000 to 5,000 Pesos & 109.00 & 21.25 & 63.16 \\
\hline 5,001 to 10,000 Pesos & 97.00 & 18.91 & 82.07 \\
\hline 10,001 Pesos and Above & 92.00 & 17.93 & 100.00 \\
\hline Total & 513.00 & 100.00 & \\
\hline
\end{tabular}


Distribution of Student-Respondents' Parents Educational Attainment

\begin{tabular}{|l|r|r|r|}
\hline \multicolumn{1}{|c|}{ Educ_id } & Frequency & Percent & $\begin{array}{c}\text { Cumulative } \\
\text { Percent }\end{array}$ \\
\hline Elementary Graduate & 143.00 & 27.88 & 27.88 \\
\hline High School Graduate & 156.00 & 30.41 & 58.28 \\
\hline College Graduate & 163.00 & 31.77 & 90.06 \\
\hline Master's Degree Holder & 43.00 & 8.38 & 98.44 \\
\hline PhD Degree Holder & 8.00 & 1.56 & 100.00 \\
\hline Total & 513.00 & 100.00 & \\
\hline
\end{tabular}

2. What are the determinants/indicators that affect the students' academic achievements along the following variables?

- Internal factors

- External factors

The Mean Scores, Interpretation and Correlation Coefficients $r$ For the Internal Factors' Indicators

\begin{tabular}{|c|c|c|c|c|c|}
\hline$\#$ & Internal Factor Indicator & $\begin{array}{l}\text { Mean } \\
\text { Score }\end{array}$ & $\begin{array}{c}\text { Interpre- } \\
\text { tation }\end{array}$ & $\begin{array}{l}\text { Pearson } \\
\text { Correlation }\end{array}$ & $\begin{array}{l}\text { Sig. (2- } \\
\text { tailed) }\end{array}$ \\
\hline 1 & Study habits & 3.0663 & Agree & .030 & .495 \\
\hline 2 & Attitude/Self-Efficacy & 3.0526 & Agree & .069 & .120 \\
\hline 3 & Physical health & 3.0799 & Agree & .054 & .226 \\
\hline 4 & Intelligence Quotient (IQ) & 2.7914 & Agree & $.104^{*}$ & .019 \\
\hline 5 & Language factor & 2.7875 & Agree & $.103^{*}$ & .019 \\
\hline 6 & Understanding of the subject matter & 2.9766 & Agree & .122 & .006 \\
\hline 7 & Critical thinking & 2.7446 & Agree & $.129^{* *}$ & .004 \\
\hline 8 & Attentive listening & 3.0507 & Agree & $.092^{*}$ & .038 \\
\hline 9 & Reading comprehension and analysis & 2.9786 & Agree & .052 & .239 \\
\hline 10 & Interest/Motivation in studies & 3.0370 & Agree & $.163^{* *}$ & .000 \\
\hline 11 & Positive outlook in life & 2.8791 & Agree & $.154^{* *}$ & .000 \\
\hline 12 & Time Management & 2.8694 & Agree & $.094^{*}$ & .033 \\
\hline \multicolumn{2}{|r|}{ Mean Score } & 2.9428 & Agree & & \\
\hline \multicolumn{6}{|c|}{ 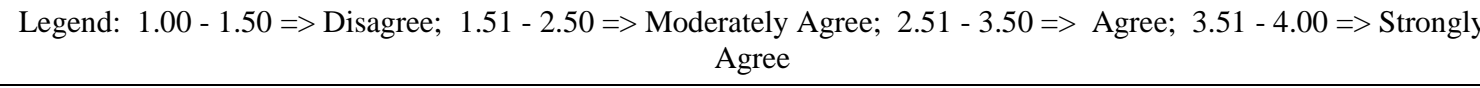 } \\
\hline \multicolumn{6}{|c|}{ *. Correlation is significant at the 0.05 level (2-tailed). } \\
\hline \multicolumn{6}{|c|}{${ }^{\star \star}$. Correlation is significant at the 0.01 level (2-tailed). } \\
\hline
\end{tabular}


The Mean Scores, Interpretation and Correlation Coefficients r For the External Factors' Indicators

\begin{tabular}{|c|c|c|c|c|c|}
\hline \# & External Factor Indicators & $\begin{array}{l}\text { Mean } \\
\text { Score }\end{array}$ & $\begin{array}{c}\text { Interpre- } \\
\text { tation }\end{array}$ & $\begin{array}{l}\text { Pearson } \\
\text { Correlation }\end{array}$ & $\begin{array}{l}\text { Sig. (2- } \\
\text { tailed) }\end{array}$ \\
\hline 1 & Education of Parents & 3.0448 & Agree & .004 & .924 \\
\hline 2 & Financial support & 3.1540 & Agree & .007 & .873 \\
\hline 3 & Learning Environment & 3.0682 & Agree & .049 & .271 \\
\hline 4 & Home Life & 3.1170 & Agree & .039 & .383 \\
\hline 5 & School Condition & 3.0585 & Agree & .082 & .063 \\
\hline 6 & Teachers' quality & 3.0604 & Agree & $.174^{* *}$ & .000 \\
\hline 7 & $\begin{array}{l}\text { Availability of facilities (e.g. classroom, } \\
\text { textbooks, equipment, and etc.) }\end{array}$ & 2.8791 & Agree & $.134^{* *}$ & .002 \\
\hline 8 & Parental support & 3.0682 & Agree & $.141^{* *}$ & .001 \\
\hline 9 & Method of Instruction & 2.8811 & Agree & $.213^{* *}$ & .000 \\
\hline 10 & Behavior of Teachers & 3.1209 & Agree & .075 & .091 \\
\hline 11 & Peer Influence & 2.6472 & Agree & $.143^{* *}$ & .001 \\
\hline 12 & Social Relationship & 2.8538 & Agree & .007 & .873 \\
\hline \multicolumn{2}{|r|}{ Mean Score } & 2.9961 & Agree & & \\
\hline \multicolumn{6}{|c|}{ Legend: $\begin{aligned} 1.00-1.50 \Rightarrow \text { Disagree; } 1.51-2.50 & =>\text { Moderately Agree; } 2.51-3.50 \Rightarrow>\text { Agree; } 3.51-4.00 \\
\Rightarrow>\text { Strongly Agree } & \end{aligned}$} \\
\hline \multicolumn{6}{|c|}{${ }^{*}$. Correlation is significant at the 0.05 level (2-tailed). } \\
\hline \multicolumn{6}{|c|}{${ }^{* *}$. Correlation is significant at the 0.01 level (2-tailed). } \\
\hline
\end{tabular}

3. Is there a significant influence of internal factors and external factors to the Academic Achievements of the students in terms of:

a. Internal factors

b. External factors

The Mean Scores, Interpretation and Correlation Coefficients $r$ For the Influence of Internal Factors' Indicators

\begin{tabular}{|c|l|c|c|c|c|}
\hline$\#$ & \multicolumn{1}{|c|}{ Internal Factors' Indicators } & $\begin{array}{c}\text { Mean } \\
\text { Score }\end{array}$ & $\begin{array}{c}\text { Interpre- } \\
\text { tation }\end{array}$ & $\begin{array}{c}\text { Pearson } \\
\text { Correlation }\end{array}$ & $\begin{array}{c}\text { Sig. (2- } \\
\text { tailed) }\end{array}$ \\
\hline & Physical Health & & & & \\
\hline 1 & I am physically healthy and capable of learning & 3.1774 & Agree & .078 & .077 \\
\hline 2 & $\begin{array}{l}\text { I cannot easily copy a lecture or assignment because } \\
\text { of my poor eyesight. }\end{array}$ & 1.7856 & $\begin{array}{c}\text { Moderately } \\
\text { Agree }\end{array}$ & $-.150^{* *}$ & .001 \\
\hline 3 & $\begin{array}{l}\text { I cannot listen very well to what my teachers say } \\
\text { because my hearing ability is impaired }\end{array}$ & 1.6472 & $\begin{array}{c}\text { Moderately } \\
\text { Agree }\end{array}$ & $-.180^{* *}$ & .000 \\
\hline 4 & I always feel weak and easily get tired in school & 2.1267 & $\begin{array}{c}\text { Moderately } \\
\text { Agree }\end{array}$ & $-.128^{* *}$ & .004 \\
\hline & Mean & 2.1842 & $\begin{array}{c}\text { Moderately } \\
\text { Agree }\end{array}$ & & \\
\hline & Attitude/Self-Efficacy & & & & \\
\hline 5 & $\begin{array}{l}\text { I am capable of accepting and handling tasks } \\
\text { especially those that are related in my studies }\end{array}$ & 2.7992 & Agree & $.092^{*}$ & .038 \\
\hline 13 & I am capable of passing all my subjects & 2.7992 & Agree & $.181^{* * *}$ & .000 \\
\hline 15 & I am a good student & 3.2086 & Agree & .081 & .067 \\
\hline & Mean & 2.9357 & Agree & & \\
\hline
\end{tabular}


The Mean Scores, Interpretation and Correlation Coefficients r For the Influence of Internal Factors' Indicators

\begin{tabular}{|c|c|c|c|c|c|}
\hline \# & Internal Factors' Indicators & $\begin{array}{l}\text { Mean } \\
\text { Score }\end{array}$ & $\begin{array}{c}\text { Interpre- } \\
\text { tation }\end{array}$ & $\begin{array}{l}\text { Pearson } \\
\text { Correlation }\end{array}$ & $\begin{array}{l}\text { Sig. (2- } \\
\text { tailed) }\end{array}$ \\
\hline & Intellectual Abilities & & & & \\
\hline 6 & I get headaches whenever I listen to different lessons & 2.1559 & Agree & $-.142^{* *}$ & .001 \\
\hline 7 & I can easily understand the lessons discussed & 2.5945 & Agree & .029 & .519 \\
\hline \multirow[t]{3}{*}{9} & I always get high scores in my quizzes and examinations. & 2.5283 & Agree & -.047 & .286 \\
\hline & Mean & 2.4263 & Agree & & \\
\hline & Study Habit & & & & \\
\hline \multirow[t]{2}{*}{8} & I always study my lessons & 2.7973 & Agree & $-.120^{* *}$ & .006 \\
\hline & Language Factor & & & & \\
\hline 10 & I can understand English instructions & 2.6901 & Agree & $.240^{* *}$ & .000 \\
\hline 11 & I can relate with my classmates and teachers & 2.8207 & Agree & $.149^{* * *}$ & .001 \\
\hline \multirow[t]{3}{*}{12} & I can speak English & 2.7076 & Agree & $.277^{* *}$ & .000 \\
\hline & Mean & 2.7394 & Agree & & \\
\hline & Interest/Motivation & & & & \\
\hline \multirow[t]{2}{*}{14} & I am interested in my studies & 3.1559 & Agree & .056 & .204 \\
\hline & Grand Mean & 2.3424 & Agree & & \\
\hline \multicolumn{6}{|c|}{ Legend: $1.00-1.50 \Rightarrow$ Disagree; $1.51-2.50 \Rightarrow$ Moderately Agree; $2.51-3.50 \Rightarrow$ Agree; $3.51-4.00 \Rightarrow>$ Strongly Agree } \\
\hline \multicolumn{6}{|c|}{ *. Correlation is significant at the 0.05 level (2-tailed). } \\
\hline \multicolumn{6}{|c|}{ **. Correlation is significant at the 0.01 level (2-tailed). } \\
\hline
\end{tabular}


The Mean Scores, Interpretation and Correlation Coefficients r For the Influence of External Factors' Indicators

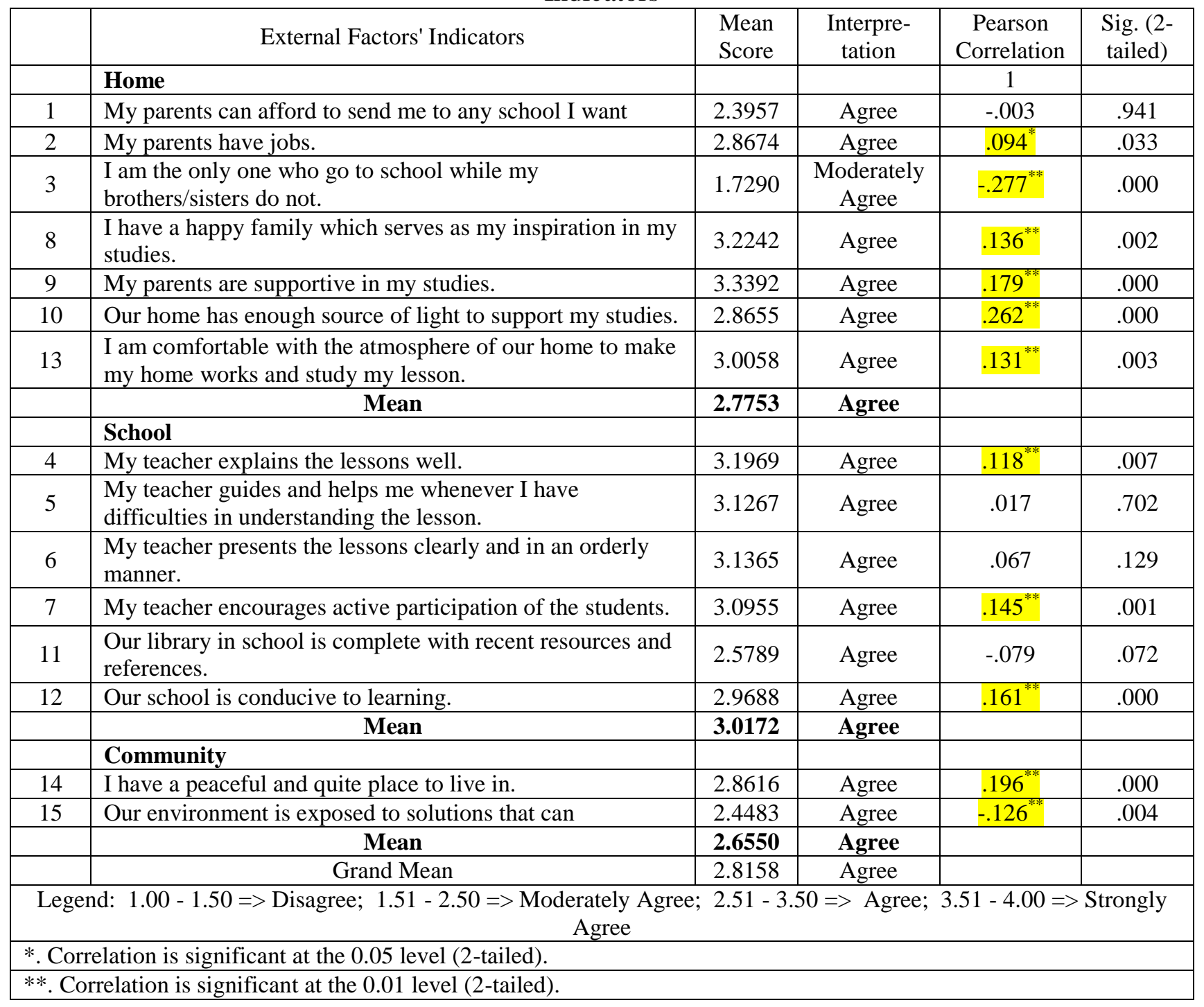

The Analysis of Variance for the Regression Analysis of the External and Internal Factors as the Independent Variables

ANOVA $^{\mathrm{a}}$

\begin{tabular}{|c|c|c|c|c|c|c|}
\hline \multicolumn{2}{|c|}{ Model } & Sum of Squares & df & $\begin{array}{c}\text { Mean } \\
\text { Square }\end{array}$ & F & Sig. \\
\hline \multirow{2}{*}{1} & Regression & 2557.617 & 4 & 639.404 & 5.606 & $.000^{\text {b }}$ \\
\cline { 2 - 7 } & Residual & 57944.524 & 508 & 114.064 & & \\
\cline { 2 - 7 } & Total & 60502.140 & 512 & & & \\
\hline
\end{tabular}

a. Dependent Variable: Achievement

b. Predictors: (Constant), ExterIn_fMean, InterFacMean, InterInf_Mean, ExterFacMean 


\section{Conclusions}

On the basis of the findings, it is concluded that the Academic Achievement is affected and influenced by various factors. However, intelligence quotient (IQ), language factor, understanding of the subject matter, critical thinking, attentive listening, interest/motivation in studies, positive outlook in life, and time management are the common indicators for internal factors. On the other hand, interest/motivation in studies was considered as having significant effect. External factors including teachers' quality, availability of facilities, parental support, method of instruction, behavior of teachers and peer influence were the common indicators and parental support had a significant effect on students' academic achievement.

\section{Recommendations}

The study recommends the following measures:

1. Parental support and involvement in students' education.

2. Hiring of competent and qualified teachers in all secondary schools in Bongao District.

3. Exposure of teachers to seminar-workshops and trainings for professional growth.

4. Provision of adequate updated facilities, instructional materials and devices.

5. More research studies conducted related to "Factors affecting students' academic achievements".

\section{References}

\section{Books}

[1] Agno, Lydia N. Principles of Teaching 2: A Modular Approach. Published in 2010 by C \& E Publishing, Inc.

[2] Aquino G. \& Miranda, N. Introduction to Psychology, Second Edition, 2003. (2005 Reprint). National Book Store.

[3] Asaad, Abubakar S., and Hailaya, Wilham M. Measurement and Evaluation: Concepts and Principles. Rex Book Store Inc. Philippine 2004.

[4] Gregorio, Herman C. Principles and Methods of Teaching. Revised Edition 1976.

\section{Thesis}

[5] Aradais, L., (1993). Teaching Effectiveness of Public School Teachers of Bongao.

[6] Gueta, Ma. Eloisa S. (1993). Relationship Between Socio-Economic Status and English Academic Achievements of Public Elementary School Pupils in Tawi-Tawi.

[7] Jailani, Hji. Fauzi (2003). Academic Achievement of Mindanao State University Tawi-Tawi Community High School Students as Predictor of 2003 System Admission and Scholarship Examination Performance.

[8] Mohammad, Sitti Malaya S. (2004). Factors Affecting Motivation and Level of Performance of Elementary and Secondary Teachers in Languyan .

\section{Internet Sources}

[9] Desrosiers, Nicole. Factors Affecting the Performance of Children in the Classroom. Updated February 2011. http//www. Ehow.com/info.

[10] Goldman et. al, 1998. Factors Affecting Students Academic performance.

[11] Hijazi, Syed T. \& Naqvi, Raza. Factors Affecting Students' Performance. http//www.mysmartschool.ph/web/studentperformance.

[12] Helen Dwight Reid Education Foundation (2011). Factors Affecting Children's' School Success

[13] Huit, W., Huitt, M., Monetti, D., \& Hummel, J. (2009): A System- Based Synthesis of Research Related to Improving Students' Academic Performance. 
[14] Jeynes, William H. Harvard Graduate School of Education. Parental Involvement and Student Achievement. December 2005.

[15] M. S. Farooq, A. H. Chaudhry, M. Shafiq, G. Berhanu. Factors Affecting Students' Quality of Academic Performance: A Case of Secondary School Level. University of Punjab, Pakistan \& University of Gothenburg, Sweden. December 2011.

[16] Newman \& Wehlage (1995). Primer: Education Issues- Variables Affecting Student Achievement. http//www.weac.org/issues-Advocacy/Resource.

[17] Radzka, Katarzyna. Factors that Affect Student Achievement. Published September 2010. http://www.educationspace360.com/index. 